\title{
SOSIALISASI PENGISIAN PROFIL BELAJAR SISWA INKLUSIF DI SDN 1 DAN MI AL-FATHIYAH LENDANG ARA KOPANG LOMBOK TENGAH
}

\author{
Heri Hadi Saputra' ${ }^{1}$ Mansur Hakim² ${ }^{2}$ Lalu Hamdian Affandi ${ }^{3}$, Husniati ${ }^{4}$, Radiusman $^{5}$ \\ 1,2,3,4,5 Program Studi Pendidikan Guru Sekolah Dasar, FKIP, Universitas Mataram \\ *e-mail: heri fkip@unram.ac.id
}

\begin{abstract}
Student learning profile is an instrument that can help teachers to identify learning difficulties experienced by students, especially those with functional barriers. Therefore, this activity aims to improve the ability of teachers in filling out student learning profiles to teachers at SDN Lendang Ara and SDN Jurit with a total of 20 participants. This activity was carried out using presentation, discussion, question and answer methods and group work. Through presentations and question and answer sessions the team provided a conceptual understanding of the nature of inclusive education in primary schools, the goals and benefits of inclusive education. The socialization of filling in the student learning profile instruments was guided through presentations and discussions between the team and the teacher. Teachers in groups accompanied by teams fill out student learning profile instruments to identify learning barriers experienced by students. This community service activity recommends that universities and the government be more intense in socializing inclusive education programs and holding capacity training for teachers to be able to present solutions for the learning of children with functional barriers.
\end{abstract}

Keywords: socialization, student learning profile, learning difficulties

\begin{abstract}
Abstrak
Profil belajar siswa merupakan instrument yang dapat membantu guru untuk mengidentifikasi kesulitan belajar yang dialami oleh siswa khususnya yang memiliki hambatan fungsional. Oleh karena itu kegiatan ini bertujuan untuk meningkatkan kemampuan guru dalam pengisian profil belajar siswa kepada guru di SDN lendang ara dan SDN jurit dengan jumlah peserta sebanyak 20 orang. Kegiatan ini dilaksanakan dengan metode presentasi, diskusi, tanya jawab dan kerja kelompok. Melalui sesi presentasi dan tanyajawab tim memberikan pemahaman konsep tentang hakikat Pendidikan inklusif disekolah dasar, tujuan serta manfaat Pendidikan inklusif. Sosialisasi pengisian intrumen profil belajar siswa dipandu melalui presentasi dan diskusi antara tim dengan guru. Guru secara berkelompok didampingi oleh tim melakukan pengisian instrument profil belajar siswa guna mengidentifikasi hambatan belajar yang dialami siswa. Kegiatan pengabdian pada masyarakat ini merekomendasikan agar perguruan tinggi maupun pemerintah lebih intens mensosialisasikan program Pendidikan inklusif serta mengadakan pelatihan kapasitas bagi guru agar mampu menghadirkan solusi bagi pembelajaran anak dengan hambatan fungsional.
\end{abstract}

Kata kunci: sosialisasi, profil belajar siswa, kesulitan belajar

\section{PENDAHULUAN}

Pendidikan menjadi instrumen kunci untuk mengembangkan kebudayaan, pedababan dan potensi kemnausiaan setiap siswa sehingga ia menjadi wajib bagi semua. Hal ini besesuaian dengan apa yang diungkapkan wardi bahwa Hakekat pendidikna inklusif adalah memanusiakan manusia, mengembangkan potensi dasar peserta didik agar berani dan mampu menghadapi rasa tertekan, mampu dan senang meningkatkan fitranhnya sebagai khalifah dimuka bumi (Wardi, 2012)

Pendidikan inklusif adalah sitem layanan pendidikan yang mensyaratkan anak berkebutuhan khusus belajar di sekolah-sekolah terdekat di kelas biasa bersama teman-teman seusianya ( Sapon Shevin dalam O’Neil 1994). Sekolah penyelenggara pendidikan inklusif adalah sekolah yang menampung semua murid di kelas yang sama. Sekolah ini menyediakan program pendidikan yang layak, menantang, tetapi disesuaikan dengan kemampuan dan kebutuhan setiap murid maupun bantuan dan dukungan yang dapat diberikan oleh para guru, agar anak-anak berhasil (Stainback, 1980). Berdasarkan batasan tersebut pendidikan inklusif dimaksudkan sebagai sistem layanan pendidikan yang mengikutsertakan anak berkebutuhan khusus belajar 
bersama dengan anak sebayanya di sekolah reguler yang terdekat dengan tempat tinggalnya. Semangat penyelenggaraan pendidikan inklusif adalah memberikan kesempatan atau kases yang seluas-luasnya kepada semua anak untuk memperoleh pendidikan yang bermutu dan sesuai dengan kebutuhan individu peserta didik tanpa diskriminasi. Penyelenggaraan pendidikan inklusif menuntut pihak sekolah melakukan

Arus kuat pengembangan pendidikan inklusif diindonesia mulai terasa dalam beberapa tahun terakhir, hal ini ditunjukkan dengan diterbitkannya beberapa peraturan yang mendukung program tersebut mulai dari tingkat pusat sampai daerah. Fakta ini tidak lepas dari mulai tumbuhnya kesadaran pemerintah dan masyarakat akan hak setiap anak untuk mendapatkan pendidikan tanpa membedakan potensi maupun hambatan serta keterbatasan fisik mereka. Selama mereka masih memiliki status sebagai warga negara Indonesia, maka mereka adalah biagian yang harus dijamin haknya untuk memperoleh pendidikan.

Rintisan pendidikan inklusif kemudiann muncul hampir disemua daerah, bahkan pengembangannya melibatkan perguruan tinggi dan organisasi non pemerintah (NGO). Selain bertujuan merekayasa kultur masyarakat tentang eksistensi anak disabilitas dengan meningkatkan rasa keberterimaan mereka Hal ini juga dilakukan guna mendapatkan potret untuh dari pelaksanaan pendidikan inklusif diindonesia.

Implementasi pendidikan inklusif disekolah dasar telah mulai dirintis sejak beberapa tahun terakhir, meski belum menjangkau semua sekolah dasar namun pelibatan beberapa sekolah dalam program ini melalui penunjukan beberapa sekolah sebagai sekolah inklusif merupakan langkah yang perlu diapresiasi. Kesadaran bersama masyarakat dan semua warga sekolah, keberpihakan kepala sekolah dalam penganggaran fasilitas, kemampuan guru dalam mengidentifikasi gejala disabilitas, kemampuan administratif dalam pengisian profil belajar siswa merupakan beberapa hal yang harus dipastikan terwujud disekolah yang mengimplementasikan pendidikan inklusif.

Setiap anak yang datang untuk belajar disekolah memiliki dasar kemampuan, potensi maupun hambatan yang berbeda-beda sehingga memberikan perlakukan yang seragam pada anak yang berbeda adalah sebuah kekeliruan. Guru-guru yang ada sejauh ini belum memiliki kecakapan dalam memberikan layanan kepada siswa dengan hambatan fungsional tertentu, sehingga mereka cenderung diperlakukan dengan cara yang sama dengan siswa normal pada saat proses pmbelajaran. Fenomena ini terjadi karena para guru tidak memiliki kemampuan untuk mengenali jenis kesulitan fungsional yang dialami siswa, sehingga berdampak tidak terpenuhinya layanan yang baik bagi siswa disabilitas.

Salah satu cara ynag dapat dilakukan untuk mengenali variasi potensi maupun hambatan belajar siswa adalah dengan mengisi Profil Belajar Siswa (PBS). Profil belajar siswa (PBS) merupakan isian yang terdiri dari sederet form berisi data siswa berupak identitas dan ciri-ciri fisik maupun mental yang dapat diamanti. Profil belajar siswa dapat membantu guru dalam mengenali siswanya secara lebih detail sehingga ia mampu menentukan teknik, metode, media, pendekatan belajar bahkan alat bantu yang tepat sesuai dengan kekhususan siswa yang bersangkutan.

Saat ini formulir Profil Belajar Siswa baru mulai diterapkan sehingga masih cukup asing bagi sebagian besar guru. Hal in berdampak pada pengisian formulir PBS yang kurang akurat. Dari beberapa kasus yang kami temukan para guru seringkali mengalami kebingungan pada saat pengisian PBS dimana mereka hurus memutuskan jenis kesulitan fungsional yang memiliki ciri atau penanda yang mirip atau hampir sama.

Akurasi isian dalam PBS sangat menentukan konklusi akhitr dari jenis kesulitan fungsional siswa yang pada akhirnya dapat dijadikan rujukan utama dalam proses pembelajaran. Kongklusi ini harus benar-benar valid karena kesalhannya akan menimbulkan kekeliruan dalam layanan bahkan dapat memunculkan stigma negatif pada peserta didik yang kemudian secara personal dan sosial berdampak negatif.

Undang-undang Nomor 20 tahun 2003 tentang Sistem pendidikan Nasional memberikan warna baru dalam penyediaan pendidikan bagi peserta didik penyandang disabilitas. Dalam penjelasannya, pasal 15 dan pasal 32 menyebutkan bahwa pendidikan khusus merupakan pendidikan untuk peserta didik yang berkelainan atau peserta didik yang memiliki kecerdasan 
luar biasa yang diselenggarakan secara inklusif atau berupa satuan pendidikan khusus pada tingkat pendidikan dasar dan menengah. Aturan terbaru yang mengatur tentang pendidikan inklusif ini, adalah dikeluarkannya Peraturan Menteri Pendidikan Nasional (Permendiknas) nomor 70 Tahun 2009 yang menyebutkan bahwa pendidikan inklusi sebagai sistem penyelenggaraan pendidikan yang memberikan kesempatan kepada semua peserta didik yang memiliki kelainan dan memiliki potensi kecerdasan dan/atau bakat istimewa untuk mengikuti pendidikan atau pembelajaran dalam lingkungan pendidikan secara bersama-sama dengan peserta didik pada umumnya.

Aktor utama dalam implementasi pendidikan inklusif ditingkat sekolah tentu saja para guru karena merekalah yang secara langsung berhadapan dengan para siswa dengan kesulitan fungsional dikelas. Dalam melaksanakan tuga sebagai guru sedapat mungkin proses pembelajaran dapat dikelola secar efektif yang ditandai dengan terlyaninya seluruh peserta didik sesuai dengan kemapuan dan hambaannya masing-masing.

Pembelajaran yang efektif adalah pembelajaran yang dilaksanakan dengan strategi yang efektif, pengelolaan kelas yang efektif, serta desain kurikulum yang efektif pula (Marzano, 2007; 5). Pembelajaran yang efektif terwujud melalui perilaku guru yang meliputi kejelasan penjelasan guru, variasi cara mengajar, orientasi tugas, dan optimalisasi keterlibatan belajar siswa (Borich, 1996; 11). Artinya, pembelajaran yang efektif hanya bisa dilakukan oleh guru yang memiliki kompetensi yang sesuai dengan persyaratan perundang-undangan.

\section{METODE}

Kegiatan ini dilaksanakan dengan metode pendampingan (coaching) yang menekankan hubungan kolaboratif antara tim pengabdian kepada masyarakat dengan guru sasaran. Metode pelaksanaan kegiatan ini meliputi, cermah berbantuan media slide, tanya jawab, diskusi dan kerja individual dalam kelompok. Metode ceramah digunakan untuk menyampaikan pengertian, jenis, dan klasifikasi hambatan belajar siswa. Metode tanya jawab digunakan untuk mengekplorasi pengalaman dan permasalahan-permasalahan yang dihadapi guru dalam layanan pembelajaran siswa inklusif. Metode diskusi digunakan untuk menstimulasi guru agar mampu mengenali secara utuh hambatan belajar yang dialami siswa sehingga secara mandiri mereka dapat melakukan pengisian profil Belajar Siswa. Selain itu metode diskusi juga digunakan untuk menumbuhkan motivasi dan semangat bagi guru agar dapat secara tepat memberikan layanan belajar kepada siswa inklusif sesuai dengan hambatna belajar yang dimiliki. Sedangkan presentasi dilakukan untuk melkaukan kroscek terhadapa hasil pengisian PBS agar dapat dijadikan acuan, diberi masukan dan pertimbangan oleh sesama guru dan tim pengabdian sehingga dapat melahirkan PBS yang tepat.

\section{HASIL DAN PEMBAHASAN}

Kegiatan sosialisasi ini di adakan pada tanggal 24 agustus 2020 di SDN Lendang ara. Kegiatan yang semula direncanakan diikuti oleh 2 sekolah yaitu SDN Lendang Ara dan MI AlFathiyah Lendang Ara kemudian di rubah dan dan diganti dengan SDN Jurit karena beberapa pertimbangan. Diantara pertimbangannya adalah bahwa SDN Lendang Ara dan SDN Jurit memiliki lokasi yang berdekatan, kedua sekolah juga sudah mengenal program Pendidikan inklusif serta lebih mudah berkoordinasi, sedangkan MI Al-Fathiyah Lendang Ara memiliki hambatan dalam ketiga hal tersebut.

Kegiatan ini dibuka oleh Kepala Sekolah SDN Lendang Ara selaku tuan rumah. Dalam sambutannya kepala sekolah menyampaikan bahwa selama ini para guru hanya melaksanakan pembelajaran secara konvensional dengan metode klasikal sehingga besar sekali kemungkinan akan ada anak yang terlambat menguasai materi ajar yang disebabkan oleh hambatan belajar yang mereka miliki, sejauh ini para guru tidak memiliki cukup kemampuan untuk mengidentifikasi anak yang memiliki masalah pembelajaran terutama hambatan fungsional yang disebabkan tidak adanya pelatihan dan sosialisasi tentang hal tersebut. Para guru dan semua pihak sekolah sebenarnya telah banyak mendengar tentang program Pendidikan inklusif namun belum sepenuhnya mengerti tentang esensi dan bentuk programnya sehingga hal tersebut hanya berhenti sebagai obrolan lalu saja. 
Pada saat yang sama kepala sekolah juga menyampaikan ungkapan syukur dan terimakasih kepada tim dari FKIP Unram yang telah menunjuk sekolah mereka sebagai mitra untuk melaksankanan kegiatan, karena dengan begitu mereka sangat yakin akan mendapatkan pengetahuan dan manfaat yang besar bagi peningkatan kualitas pembelajaran khususnya tentang bagaimana cara menangani masalah anak yang memiliki hambatan fungsional.

Kegiatan selanjutkan diteruskan dengan penyampaian materi dari tim pengabdian FKIP unram tentang, hakikat pendidikan inklusif di sekolah dasar, jenis-jenis Kesulitan Fungsional dan hambatan belajar siswa di sekolah Inklusif, Tentang Profil Belajar Siswa inklusif lalu diteruskan dengan Diskusi Kelompok Dan Simulasi Pengisian Profil Belajar Siswa serta diakhiri dengan sesi Presentasi hasil Pengisian Formulir Profil Belajar Siswa (PBS).

Dalam penyampainya, tim pengabdian masyarakat FKIP Unram menyampaikan bahwa hak untuk memperoleh layanan belajar yang baik merupakan hak setiap siswa tanpa membedakan latar belakang sosial, budaya, ras, suku berdasarkan potensi yang mereka miliki. Dalam kenyataannya tidak semua siswa memiliki potensi dan modal belajar yang sama sehingga Sebagian diantara mereka mengalami keterlambatan pemahaman dan perkembangan intelektual, keterlambatan perkembangan emosional bahkan memiliki hambaran fungsional fisik dalam belajar. Anak-anak yang memiliki hambatan fungsional ringan dalam belajar dapat ditempatkan dikelas yang sama dengan anak-anak normal sehingga mereka dapat merasakan proses pembelajan yang normal, bergaul dengan orang yang normal serta dapat melatih siswa lain untuk lebih bisa menghargai kekurangan orang lain. hal ini memiliki banyak sekali manfaat salah satunya adalah mengurangi perundungan (bullying) yang sering dialami oleh anak-anak yang lamban belajar maupun memiliki hambatan fungsional.

Wilayah pedesaan merupakan wilayah yang rentan mengalami masalah Kesehatan anak yang dapat berimplikasi pada ketidak seimbangan perkembangan potensi belajar maupun fisik anak. ditambah lagi masalah budaya dan keluarga yang tidak utuh yang selalu berdampak buruk terhadap perkembangan fisik, emosional, spiritual maupun intelektual anak. Banyaknya siswa yang tidak memiliki keluarga yang lengkap, diasuh oleh kakek/nenek karena ditinggal cerai oleh orang tua mereka juga memiliki potensi besar mengalami masalah pembelajaran.

Salah satu alternatif yang bisa digunakan untuk mengatasi hal tersebut adalah dengan menerapkan Pendidikan inklusif yang mana program ini telah dicanangkan dan mulai diimplementasikan dikabupaten Lombok Tengah namun belum optimal. Bebrapa factor diidentifikasi sebagai penyebanya seperti kurangnya sosialisasi program, kurangnya guru pendamping khusus, tidak adanya sosialisasi instrumen profil belajar siswa dan lain-lain. memaksimalkan program Pendidikan inklusif serta membantu siswa mengatasi hambatan belajarnya adalah tugas yang mulai, hal tersebut dapat dimulai dengan mengenali dan mendeteksi sejak dini secara baik hambatan belajar apa yang dialami oleh siswa. Dengan mengenali lebih awal hambatan belajar yang dialami maka akan semakin mudah menentukan jenis bantuan dan dukungan belajar apa yang akan diberikan oleh guru kepada siswa yang bersangkutan.

Profil belajar siswa (PBS) adalah instrument yang berisi profil siswa yang mengalami hambatan fungsional belajar berisi informasi tentang jenis hambatan serta kebutuhan siswa dalam pembelajaran bahkan juga potensi non akademik yang dimiliki siswa. Dari informasi yang ada pada PBS tersebut akan membantu guru untuk menentukan jenis perlakuan atau media apa yang akan diberikan kepada siswa untuk mengatasi hambatan belajar yang dialami (Setiawan, 2020a; Setiawan, 2020b; Oktaviyanti, 2021).

Kegiatan pengabdian pada masyarakat ini menghasilkan beberapa hal yang berkaitan dengan peningkatan layanan bagi siswa yang mengalami hambatan fungsional belajar.

Adapun hasil yang dapat diamati adalah

1. Peningkatan pemahaman dan kesadaran terhadap eksistensi siswa yang memiliki hambatan fungsional

Sebelum program ini dilaksanakan para guru mengakui bahwa selama ini mereka dapat memperkiraan siswa-siswa yang memiliki hambatan belajaran yang mereka amati dalm proses belajar maupun data hasil belajar. namun mereka belum memiliki pengetahuan untuk menentukan jenis hambatan apa yang sesungguhnya dialami siswa. Hal tersebut menyebabkan mereka tidak mampu memberikan bantuan belajar yang tepat bagi siswa. Hal lain yang 
diungkapkan adalah jika mereka menemukan siswa yang mengalami hambatan fungsional belajar maka mereka hanya akan membiarkan saja tanpa mampu melakukan apapun serta memilih fokus untuk melayani anak-anak normal. Kesan lain yang muncul juga para guru cenderung menganggap siswa dengan hambatan fungsional hanya menjadi beban dari proses pembelajaran.

Setelah kegiatan ini dilaksanakan para guru mulai menyadari tanggung jawab mereka sebagai pendidik yang utuh yang harus memberikan layanan kepada seluruh siswa mereka tanpa membedakan keadaan, kekurangan maupun kecacatan mereka. Dari segi kompetensi para guru telah mampu mengidentifikasi jenis-jenis hambatan yang dialami siswa serta mencoba membuat langkah penanganan guna membantu siswa mengatasi hambatn belajarnya.

2. Dokumen Profil Belajar Siswa (PBS)

Profil Belajar Siswa (PBS) merupakan dokumen yang berisi informasi personal tentang siswa yang memiliki hambatan fungsional. Dokumen tersebut secara ideal harus diisi oleh guru bersama orang tua agar informasi yang didapatkan lebih komprehensif. Namun dalam sosialisasi ini tim belum mampu melibatkan orang tua dalam pengisian PBS sehingga disiasati dengan mengisi dokumen secara tim oleh guru kelasnya bersama guru kelasnya pada tahun sebelumnya. Hal ini dilakukan agar guru kelas yang membinanya saat ini mendapatkan informasi yang lebih banyak tentang profil siswa tersebut guna dapat merumuskan bentuk layanan yang akan diberikan bagi siswa yang bersangkutan.

Dokumen ini kemudian dijadikan sebagai dokumen sekolah yang diharapkan dapat bermanfaat dalam meningkatkan layanan belajar bagi siswa yang memiliki kesulitan belajar serta duplikatnya diberikan kepada tim sebagai hasil kegiatan.

\section{KESIMPULAN}

a. Guru memiliki antusiasme yang tinggi untuk mengikuti sosialisasi pengisian profil belajar siswa sebagai pedoman untuk mengenali jenis hambatan belajar siswa.

b. Beberapa tantangan yang dihadapi guru dalam memberikan layanan belajar bagi siswa dengan hambatan fungsional adalah rendahnya kemampuan guru dalam mengenali hambatan belajar sejak dini, kurangnya sosialisasi dari pihak perguruan tinggi dan pemda terkait Pendidikan inklusif serta kurangnya sarana pendukung dalam pembelajaran

c. Profil belajar siswa menjadi instrument kunci bagi guru dalam upaya memaksimalkan layanan pembelajaran bagi para siswa yang memiliki hambatan fungsional agar mereka mendapatkan hak yang sama dengan siswa normal baik secara akademik maupun social.

\section{DAFTAR PUSTAKA}

Budiyanto. (2017). “Pengantar Pendidikan Inklusif'.prenadamedia grup. Jakarta.

Oktaviyanti, I., Nasaruddin., Setiawan, H., \& Jiwandono, I. S. (2021). Identifikasi Kesulitan Fungsional Siswa SDN Peresak Bebuak Kecamatan Kopang Kabupaten Lombok Tengah. Jurnal Ilmiah Profesi Pendidikan. 6 (1), DOI: https://doi.org/10.29303/jipp.v6i1.131.

Marzano, R.J., Marzano, J.S., Pickering, D.J. (2003)." Classroom Management That Works; Researchbased Strategies for Every Teacher". Alexandria, VA; ASCD

Mujito, dkk, (2012). "Pendidikan Inklusif", baduose media jakarta Hornby

Mitchell david, (2008) "what really works in special and inklusive educatioan". Rauletge.

O'Neil,J.(1994/1995).Can inclusion work. A Conversation With James Kauffman and Mara SaponShevin. Educational Leadership. 52(4) 7-11.

Rombot, Olifia. (2017). Pendidikan Inklusi. Diakses dari: https://pgsd.binus.ac.id/2017/04/10/pendidikan-inklusi/. (diunduh 23 oktober 2019).

Setiawan, H., Aji, S. M. W., \& Aziz, A. (2020a). Tiga Tantangan Guru Masa Depan Sekolah Dasar Inklusif. BRILIANT: Jurnal Riset dan Konseptual. 5 (2), p. 241 - 251. DOI: http://dx.doi.org/10.28926/briliant.v3i4.458.

Setiawan, H., Oktaviyanti, I., Jiwandono, I. S., Affandi, L. H., Ermiana, I., \& Khair, B. N. (2020b). Analisis Kendala Guru Di Sdn Gunung Gatep Kab. Lombok Tengah Dalam Implementasi Pendidikan Inklusif. Didaktis: Jurnal Pendidikan dan Ilmu Pengetahuan. 20 (2) p. 169 - 183. DOI: http://dx.doi.org/10.30651/didaktis.v20i2.4704. 
Skidmare, David.(2004). Inclusion the Dynamic of School Development. New York : Open University Press.

Tiffany. (2017). "17 Karakteristik Anak Berkebutuhan Khusus". Diakses dari: https://www.google.com/amp/s/dosenpsikologi.com/karakteristik-anak berkebutuhankhusus/amp. (diunduh19 oktober 2019).

Wijaya, David. (2019). “Manajemen Pendidikan Inklusif”. Jakarta: Prenadamedia. 